\title{
Enhancing engineering education in the elementary school
}

\section{Authors: Juliana Utley, Toni Ivey, Rebekah Hammack, and Karen High}

This is the peer reviewed version of the following article: see full citation below, which has been published in School Science and Mathematics, found in final form at DOI: $10.1111 / \mathrm{ssm} .12332$. This article may be used for non-commercial purposes in accordance with Wiley Terms and Conditions for Self-Archiving.

Utley, Juliana, Toni Ivey, Rebekah Hammack, and Karen High. "Enhancing engineering education in the elementary school." School Science and Mathematics 119, no. 4 (April 2019): 203-212. DOI:10.1111/ssm.12332.

Made available through Montana State University's ScholarWorks

scholarworks.montana.edu 


\title{
Engineering Education in the Elementary School
}

\section{Enhancing Engineering Education in the Elementary School}

\begin{abstract}
The Next Generation Science Standards emphasize the inclusion of engineering practices throughout the K-12 science curriculum. Therefore, elementary educators need to be knowledgeable about engineering and engineering careers so that they can expose their students to engineering. The purpose of this study was to examine the effect of engineering professional development on in-service elementary teachers': (a) knowledge and perceptions regarding engineering and (b) self-efficacy of teaching engineering. This quantitative study revealed that even one professional development opportunity can help to alleviate some misconceptions about the work of engineers and what constitutes technology, as well as increase teachers' confidence to teach engineering concepts.
\end{abstract}

Keywords: engineering education, professional development, elementary, self-efficacy 


\section{Engineering Education in the Elementary School}

\section{Enhancing Engineering Education in the Elementary School}

\section{Introduction}

The United States' economy is dependent on technological development and engineering is critical to the nation's capacity for innovation (National Research Council, 2010). Because tomorrow's innovators are today's children, exposing children to engineering education during the elementary and middle school grades is important as evidence suggests many students decide if they want to pursue a STEM career prior to entering high school (Wyss, Heulskamp, \& Siebert, 2012). Personal interest is a strong factor that influences career choice (Hall, Dickerson, Batts, Kauffmann, \& Bosse, 2011) and can be shaped by the knowledge and views of teachers (Maltese \& Tai, 2010). Wilkins (2009) found that elementary teachers ranked mathematics and science as their least favorite subjects to teach. This is problematic to engineering education because the Next Generation Science Standards ([NGSS], NGSS Lead States, 2013) incorporate engineering practices throughout the K-12 science curriculum. While many elementary teachers perceive that they are ill prepared to teach science (e.g., Czerniak \& Haney, 1998), they must now also learn to incorporate engineering concepts into their elementary classrooms.

Traditionally, teacher preparation programs have not prepared teachers to incorporate engineering practices into their curriculum. In fact, Litowitz (2014) reported that there are only 24 undergraduate engineering/technology focused accredited teacher preparation programs in the country with an enrollment of at least 20 students, and these programs typically focus on secondary education. In 2016, the National Center for Education Statistics estimated that US public schools employed 3.1 million full time teachers, responsible for educating 50.4 million students. Further, Katehi, Pearson, and Feder (2009) estimated that there are only 18,000 K-12 teachers in the country who have been trained to teach engineering. While the number of 


\section{Engineering Education in the Elementary School}

teachers prepared to teach engineering has likely increased since 2009 , the small number of teacher education programs focused on engineering education suggests that relatively few teachers begin their careers prepared to teach engineering. These facts point to the need for quality engineering focused professional development for in-service teachers.

\section{Purpose of the Study}

The purpose of this study was to examine the effect of an engineering focused professional development program on in-service elementary teachers' knowledge and perceptions regarding engineering and their self-efficacy of teaching engineering. In particular, we sought to address the research question: How did participation in an engineering focused professional development program influence elementary teachers' (a) perceptions of engineering and technology, (b) science content knowledge, and (c) engineering teaching efficacy?

\section{Related Literature}

\section{Perceptions of Engineering and Technology}

The National Research Council (2012) defined technology as "any modification of the natural world made to fulfill human needs or desires" (p. 202). Technology, however, is frequently misunderstood and restricted to a more narrow definition of objects requiring the use of electricity (Cunningham, 2018; Cunningham, Lachapelle, \& Lindgren-Stricher, 2005). Further, the National Research Council (NRC) defines engineering as "a systematic and often iterative approach to designing objects, processes, and systems to meet human needs and wants" (NRC, 2012, p. 202). According to the National Academy of Engineering (2008), the majority of the general United States population hold preconceived misconceptions about engineers that do not align with the NRC's definition. The work of engineers and engineering technologists are often confused with each other (National Academy of Engineering, 2015) as well as with the 


\section{Engineering Education in the Elementary School}

work of scientists (Oware, Capobianco, \& Diefus-Dux, 2007). Teachers have been reported to hold similar misconceptions of engineering (Cunningham, Lachapelle, \& Lindgren-Streicher, 2005; Hammack \& Ivey, in press).

Cope and Ward (2002) suggested that teachers' perceptions of engineering influence their approaches to teaching engineering. Furthermore, teaching styles affect students' learning outcomes related to engineering, making teachers' perceptions of engineering an important factor influencing students' perceptions of engineering (Cope \& Ward, 2002). Teachers are likely to have a limited view of engineers (Hammack \& Ivey, in press; Nadelson, Sias, \& Seifert, 2016). In fact, Cunningham, Lachapelle, and Lindgren-Streicher (2006) found that elementary teachers have an overly broad idea of what engineers do and confuse the work of engineers with that of construction workers, electricians, and automotive mechanics. Further, in a statewide survey of elementary teachers, Hammack (2018) found that some elementary teachers hold a misconception of engineering as being extremely difficult and only appropriate for advanced students. Additionally, Knezek, Christensen, and Tyler-Wood (2011) found that the STEM perceptions of preservice elementary teachers were not significantly different from middle school students' perceptions. This highlights the need to reform preservice elementary teacher programs to include additional STEM training (DeJarnette, 2012).

\section{Knowledge of Engineering}

Effective classroom instruction requires a teacher to possess subject matter content knowledge, curricular knowledge, and pedagogical content knowledge relative to the subject they are teaching (Shulman, 1986). Most teachers, however, lack the knowledge of engineering content, curriculum, and teaching strategies (Cunningham, 2007) that are needed to effectively implement pedagogical methods associated with teaching K-12 engineering (Nadelson et al., 


\section{Engineering Education in the Elementary School}

2016). The discipline specific content knowledge an engineer must use is highly dependent upon the specific context in which he or she is working. This same principle applies to K-12 engineering activities, as the underlying content knowledge teachers must possess when teaching an engineering lesson will be specific to the context of the design challenge they are presenting (Cunningham \& Kelly, 2017). The fact that the Disciplinary Core Ideas for engineering that are found in NGSS are written as engineering design standards, rather than specific content standards, illustrates this idea. As such, a list of specific disciplinary content knowledge required to teach engineering at the elementary level cannot be generated, resulting in a need for teacher professional development programs with a focus on familiarizing teachers with engineering design and the curriculum and strategies that can be used to teach design.

Elementary teachers have reported a lack of familiarity with engineering (Hammack \& Ivey, in press; Yasar, Baker, Robinson-Kurpius, Krause, \& Roberts, 2006) and limited experience teaching engineering (Hammack \& Ivey, in press). Researchers (e.g., Sun \& Strobel, 2013; Rogers \& Portsmore, 2004) found that K-12 teachers (a) were rarely exposed to engineering, (b) were unfamiliar with how to teach engineering in their classrooms, and (c) relied heavily on pedagogical strategies used in other content areas. Teachers with limited experience in engineering education may lack the knowledge needed to properly guide students through the engineering design process and address students' questions about engineering as they arise (National Academy of Engineering and National Research Council, 2009). Because teachers are uncomfortable teaching what they do not know or are unfamiliar with (Brophy, Klein, Portsmore, \& Rogers, 2008), and many pre-kindergarten through eighth grade teachers have limited STEM content knowledge (Brophy et al., 2008), they may avoid teaching engineering.

\section{Teacher Efficacy}




\section{Engineering Education in the Elementary School}

Teacher efficacy, as described by Guskey and Passaro (1984), is a teacher's belief about how much he or she can influence student learning. Teacher efficacy consists of two dimensions - general teaching efficacy (GTE) and personal teaching efficacy (PTE) (Gibson \& Dembo, 1984). GTE is a teacher's belief that external factors (such as socioeconomic background and parental involvement) limit his or her ability to bring about student learning, while PTE is a teacher's belief that he or she has the ability to elicit student learning. Teacher efficacy is situation specific, meaning that it changes based on the context in which a teacher is teaching, changing with variables such as student characteristics (e.g., age, socioeconomic status, English language proficiency) and subject matter (Tschannen-Moran, Woolfolk Hoy, \& Hoy, 1998).

Gibson and Dembo (1994) developed the Teaching Efficacy Scale (TES) to measure both GTE and PTE. Because teacher efficacy varies with subject matter, researchers have adapted the TES to conduct studies related to specific content areas such as mathematics (Gresham, 2008; Utley, Moseley \& Bryant, 2005), science (Enochs, Smith, \& Huinker, 2000; Enochs, Riggs, \& Ellis, 1993; Riggs \& Enochs, 1990), and engineering (Yoon, Evans, \& Strobel, 2014).

Literature related to elementary teachers' engineering self-efficacy is sparse; however, studies reveal that elementary teachers appear to have a pronounced lack of comfort with engineering (e.g., Hammack \& Ivey, in press; Orr, Quinn, \& Rulfs, 2007; Cunningham, Lachapelle, \& Lindgren-Streicher, 2006). According to a 2012 national survey, only $4 \%$ of elementary teachers said they felt prepared to teach engineering (Banilower, Smith, Weiss, Malzahn, Campbell, \& Weis, 2013). Several studies have found that elementary teachers are apprehensive and uncertain about the teaching of engineering concepts and practices in the classroom (e.g., Cunningham, et al., 2006; Orr, et al., 2007). In light of evidence that indicates 


\section{Engineering Education in the Elementary School}

teachers tend to avoid teaching content that they are uncomfortable with (Appleton, 2003), they may forfeit opportunities for students to learn about engineering in their classroom.

In a state-wide survey of K-5 public school teachers, Hammack and Ivey (2017) used the Teaching Engineering Self-efficacy Scale (TESS) developed by Yoon et al. (2014) to gauge elementary teachers' efficacy related to engineering pedagogical content knowledge, engineering engagement, engineering classroom discipline, and engineering outcome expectancy. They found that K-5 teachers reported having lower engineering teaching efficacy related to pedagogical content knowledge than for the other measured areas, indicating that teachers feel less secure in their knowledge of engineering and which activities to use with their students than in their abilities to engage their students in engineering and manage their classrooms during engineering activities.

\section{Engineering is Elementary $(\mathrm{EiE}) \mathbb{}$}

Here we include information regarding the Engineering is Elementary $\left(\right.$ EiE) ${ }^{\circledR}$ curriculum that was developed by the Boston Museum of Science. It is an engineering-focused curriculum for grades 1-5 (Hester \& Cunningham, 2007) which has been used with approximately 10 million students and 110,000 teachers. The EiE® team developed 20 units, each one corresponding to a commonly taught science topic in elementary grades and one field of engineering. Each unit was developed to be implemented using student-centered teaching methods, and all $\mathrm{EiE} \AA$ units were extensively piloted, field tested, and revised multiple times before they were released for public use (Cunningham \& Lachapelle, 2014).

When asked to describe barriers to incorporating engineering into their lessons, elementary teachers have reported a lack of time to teach engineering due to administrative directives to focus on literacy, as well as limited time to identify activities and develop lessons 


\section{Engineering Education in the Elementary School}

(Hammack, 2016). EiE® offers a possible solution to these described barriers because the units are already planned and organized for the teacher, and each unit begins with a storybook that sets the background for an engineering design challenge, providing multiple opportunities for teachers to incorporate literacy standards when teaching the unit. This could be a partial explanation for the wide spread use of the EiE® curriculum to date. The EiE team is currently engaged in a large efficacy study of the impacts of EiE® curriculum. Initial results point to positive impacts of the EiE® curriculum (Lachapelle \& Cuningham, 2017); however, there is insufficient evidence to support that the use of EiE® curriculum is superior to other engineering curricula.

\section{Engineering Focused Professional Development}

The inclusion of engineering standards within the Next Generation Science Standards necessitates the availability of engineering focused professional development for in-service teachers. The components and results of these professional development programs are now beginning to surface in the research literature. Studies show that participating in engineeringfocused professional development workshops results in increased knowledge of engineering content (Duncan, Diefus-Dux, \& Gentry, 2011; Macalalag et al., 2010; Zarske, Sullivan, Carlson, \& Yowell, 2004), engineering design (Yoon, Diefus-Dux, \& Strobel, 2013), and science content (Macalalag et al., 2010; Zarske et al., 2004).

While participating in professional development can enhance teacher knowledge, Donna (2012) cautions that one experience is not enough and teachers need extended professional development to build knowledge and influence pedagogical strategies. In fact, Cunningham and Carlsen (2014) suggest that it can take three to six years for teachers to feel comfortable incorporating engineering into their classrooms. This point is illustrated in studies offering 


\section{Engineering Education in the Elementary School}

professional development using EiE® materials (Cunningham, Lachapelle, and Keenan, 2010) as well as those using other engineering curricula (Zarske et al., 2004). Cunningham et al. (2010) reported that prior to participating in EiE® curriculum training, elementary teachers had no or limited understanding of the big ideas presented and reported feeling unprepared to teach engineering content and design. After completing a six-hour hands-on training, these same participants reported a minimal to moderate understanding of engineering content and design and only felt moderately prepared to teach engineering to their students. Further, Cunningham et al. (2010) found that while participating in the six hour EiE® training improved participants' understanding of engineering and technology, it did not change the science and math pedagogical strategies they used in their classrooms. Likewise, teachers participating in a two-day engineering focused workshop utilizing curricula developed at University of Colorado at Boulder felt that they still needed additional professional development to strengthen their confidence in teaching engineering content (Zarske et al., 2004).

After conducting a thorough review of the literature, Reimers, Farmer, and Klein-Gardner (2015) created the Standards for Preparation and Professional Development for Teachers of Engineering. According to these standards, professional development should 1) address the "fundamental nature, content, and practices of engineering" (p. 41) to promote engineering content knowledge; 2) "emphasize engineering pedagogical content knowledge" (p. 41); 3) "make clear how engineering design and problem solving offer a context for teaching standards of learning in science, mathematics, language arts, reading, and other subjects" (p. 42); 4) "empower teachers to identify appropriate curriculum, instructional materials, and assessment methods" (p. 43); and 5) "be aligned to current educational research and student learning standards" (p. 43). 


\section{Engineering Education in the Elementary School}

Similarly, based on five years of conducting EiE® professional development with over 3000 elementary teachers, Sargianis, Yang, and Cunningham (2012) shared what they believe to be key components of effective engineering professional development. These components include: 1) engaging participants in hands-on, active learning experiences; 2) engaging participants as learners; 3) facilitators model effective pedagogical strategies; 4) facilitators use informal, formative assessment to direct activities; 5) participants are engaged in activities that allow them to construct foundational knowledge of engineering design and the work or engineers; 6) participants are given the opportunity to switch between student hats and teacher hats during the training; 7) participants work in collaborative groups; 8) participants are given time to reflect and debrief over the experiences; and 9) participants are given time to work in small groups to plan their own classroom implementation.

\section{Methods}

This article reports on a quantitative study of 30 elementary teachers from a Midwest state who participated in an $\mathrm{EiE} 囚$ professional development (PD) workshop. As a disclaimer, the authors of this study are not affiliated with EiE® and this study was conducted independently by the researchers and not associated with or conducted for the EiE® company. The researchers selected the EiE® curriculum because it was a widely available and well-known engineering curriculum developed for the elementary classroom. Further, the authors had independently received training in providing professional development with this curriculum. As such, the curriculum was a good fit for this professional development program. A repeated measures 


\section{Engineering Education in the Elementary School}

design was used to measure changes in teachers' perceptions of engineering and their selfefficacy in teaching engineering.

\section{Participants and Description of PD}

Elementary in-service teachers $(n=30)$ from the Midwest completed a series of engineering education workshops. Teachers attended two full-day workshops, occurring one month apart, focused on EiE® curriculum kits (http://www.eie.org). The four, female facilitators of the workshop included a middle school teacher who taught engineering courses, a science education faculty, a mathematics education faculty, and chemical engineering professor. The science and mathematics education faculty had completed training for EiE® to conduct the workshops. Further, all facilitators had experience in providing engineering education training to educators. For this professional development intervention, the facilitators followed the EiE® professional development model but also supplemented the EiE® curriculum by having focused science content conversations with teachers during the training sessions. At each training day, the facilitators provided training on two different $\mathrm{EiE} \otimes$ curriculum units: fourth grade teachers received training on A Slick Solution: Cleaning an Oil Spill and A Long Way Down: Designing Parachutes while the fifth grade teachers received training on An Alarming Idea: Designing Alarm Circuits and To Get to the Other Side: Designing Bridges. In between these two workshops, teachers also received a half-day training session on the Family Engineering curriculum (http://www.familyengineering.org/). Teachers met for a final half-day training session where they participated in a focus group discussion and competed an engineering design challenge.

Participants were primarily female (80\%) and five teachers indicated they were of Native American descent (all others white). Teachers taught either $4^{\text {th }}$ or $5^{\text {th }}$ grade and ranged 


\section{Engineering Education in the Elementary School}

from first year teachers to seasoned teachers with more than 20 years teaching experience. Given the choices of mathematics, science, reading/language arts, fine art, and social studies, baseline data collected from teachers indicated that only $20 \%$ were most comfortable teaching science; however, nearly half of these elementary teachers indicated that they were most comfortable teaching mathematics, which is atypical of the elementary teacher population (Wilkins, 2009). Further, all but one teacher attended the workshops with at least one colleague from their school.

\section{Measures}

Three of the four instruments used in the study were used not only to assess participants' beliefs or content knowledge but for teachers to experience some of the assessments directly aligned with and included in the EIE® curriculum. For example, to measure changes in participants' beliefs about engineering, this study used participant results from two assessment instruments included within the EiE® curriculum, What is an Engineer? and What is Technology?. These instruments were created and validated by the developers of the EIE® curriculum (Capobianco, Diefes-dux, Mena, \& Weller, 2011; Lachapelle, Hertel, Jocz \& Cunningham, 2013) and are the same measures that teachers would use with their own students. The What is an Engineer? instrument assesses changes in participants' understanding of the work of an engineer. This instrument consists of 19 yes/no statements describing the work of an engineer and one open-ended question: What is an engineer?. A similar instrument, What is Technology?, measures changes in participants' beliefs about what constitutes technology. This instrument consists of 20 images and asks participants to select those they consider examples of technology. Following these images, participants define the term technology in their own words. 


\section{Engineering Education in the Elementary School}

For both of these instruments, a percentage of correct items was calculated. Only closed-ended responses are a part of the current analysis.

Additionally, teachers took student content exams included within the EIE® curriculum kits, which are also available on the EiE® website (http://www.eie.org). These content exams focus on the science content linked to the design challenge. Teachers took only those content exams associated with the curriculum kit on which they received training. These tests are primarily intended to be used as pre to post measures with elementary children. Researchers included these measures for educators because we had noticed that preservice teachers in elementary science methods courses had difficulty answering the items. Since the science content on these exams are foundational for the engineering design challenges, we included these measures with this in-service teacher population as a way to assess their content knowledge of the topics aligned to the kits on which they were receiving training. All content exams were scored based on percentage of correct items.

The 23 item, 6-point Likert scale, Teaching Engineer Self-efficacy Scale ([TESS], Yoon \& Strobel, 2014) was used to assess changes in teachers' self-efficacy in their ability to teach engineering concepts. The TESS consists of four subscales: engineering pedagogical content knowledge self-efficacy ( 9 items), engineering engagement self-efficacy (4 items), engineering disciplinary self-efficacy (5 items), and engineering outcome expectancy (5 items). While not typical of teacher self-efficacy instruments, Yoon and Strobel (2014) suggest that the overall teaching engineering self-efficacy of an individual can be gauged by summing the scores on these subscales. Reliability analysis suggests that the TESS has good internal consistency across the subscales with Cronbach's $\alpha$ ranging from 0.89 to 0.96 and an overall reliability of 0.98 . 


\section{Engineering Education in the Elementary School}

\section{Data Collection and Analysis}

Researchers utilized a repeated measures design throughout the training. Prior to any training, teachers completed the TESS, What is Engineering? and What is Technology? scales. Teachers completed the What is Engineering? and What is Technology? scales again at the conclusion of each of the two full EiE® training days (one month apart). The TESS was administered as a post test at the conclusion of all PD activities. Finally, the science content tests were administered as a pre-post test at the beginning and end of each EiE® training day.

We utilized nonparametric statistics due to the small sample size and non-normal distribution of data. When the same measure was collected at three separate points in time, we utilized a Friedman's Test of Multiple Measures to determine if changes were statistically significant. If the Friedman's Test determined significance, we employed Pairwise Wilcoxon Signed Ranks tests as a post hoc analysis to determine at which points significant changes were made within our sample. We utilized the nonparametric Wilcoxon Matched Pairs Signed Ranks Test for measuring change in all content tests and Teaching Engineering Self-efficacy Scale.

\section{Results}

\section{What is Technology?}

Table 1 displays descriptive statistics for participants' scores on the What is Technology? instrument. Application of Friedman's test shows that there are some statistically significant changes $\left(\chi^{2}=19.023, p<0.001\right)$ in the distribution of What is Technology? scores over the three time points. A pair-wise application of the Wilcoxon Signed Ranks test shows that scores on the first post-test $(z=-2.971, n=29, p=.003, r=.55)$, and the second post-test $(z=-3.089, n=28$, $p=.002, r=.58)$ are significantly higher than the baseline scores; however, there was no significant change between the first and second post-test scores. Further, the calculated effect 


\section{Engineering Education in the Elementary School}

size values $(r=.55$ and $r=.58)$ suggest a moderate to high practical significance between the pre and posttests. These results indicate that elementary teachers can deepen their understanding of technology through a single professional development opportunity that directly addresses the meaning of technology.

\section{What is an Engineer?}

Table 2 displays descriptive statistics for participants' scores on the What is an Engineer? test. Application of Friedman's test shows that there are some statistically significant changes $\left(\chi^{2}\right.$ $=6.348, p=.042)$ in the distribution of What is an Engineer? scores over the three time points. A pair-wise application of the Wilcoxon Signed Ranks test shows that scores on the first posttest $(z=-2.588, n=28, p=.010, r=.49)$ and the second post-test $(z=-2.304, n=27, p=.021, r$ $=.44$ ) were significantly higher than the baseline scores; there was no significant change between the first and second post-test scores. Further, the calculated effect size values $(r=.49$ and $r=.44$ ) suggest a moderate significance between the pre and posttests. Similar to the What is Technology? findings, these results indicate that a single professional development that focuses on the activities of an engineer and the engineering design process can help to alleviate elementary teachers misconceptions of the work of an engineer.

\section{Science Content Knowledge}

Table 3 displays descriptive and inferential statistics for participants' pre/post content test scores for the individual $\mathrm{EiE} \circledast$ kits on which they received training. Application of the Wilcoxon Sign Ranks tests shows that there were statistically significant gains on the pre and post measures for all content exams given. Findings suggest that these elementary teachers made significant gains on content exams that were designed for elementary-aged children. In this instance, teachers' median scores increased by the equivalent of a letter grade. Further, the 


\section{Engineering Education in the Elementary School}

calculated effect size values ranging from 0.48 to 0.66 suggest a moderate effect on the teachers' gains on the content exams (Cohen, 1988). These findings may indicate that supplementing the EiE® curriculum with focused discussions on the applicable science content was beneficial to the teachers by either activating knowledge they may have forgotten, deepening their current understandings, or taught them something new.

\section{Teaching Engineering Self-Efficacy}

Descriptive and inferential statistics of participants' TESS scores are displayed in Table 4. Results indicate there was a significant increase in participants' overall self-efficacy in teaching engineering scores $(z=-3.610, p<.001, r=.67)$. Additionally, participants made significant gains on all but the Engineering Disciplinary Self-efficacy subscale. Further, the calculated effect size values ranging from 0.50 to 0.67 suggest a moderate to high practical significance between the pre and posttests. Overall, the engineering education workshops had a positive impact on their self-efficacy related to teaching engineering.

\section{Discussion and Conclusions}

In this teacher professional development study, elementary teachers attended three separate engineering-focused professional development opportunities spaced over the course of a semester. The repeated measures design showed that participating in this professional development program increased teachers' understanding of engineering and technology, science content knowledge, and engineering teaching efficacy.

Our results are generally consistent with findings from other studies of elementary teachers partaking in engineering education professional development. As reported in prior research, this study also indicates that teachers participating in engineering-focused professional development workshops developed increased knowledge of engineering content (Duncan, 


\section{Engineering Education in the Elementary School}

Diefus-Dux, \& Gentry, 2011; Macalalag et al., 2010; Zarske, Sullivan, Carlson, \& Yowell, 2004) and science content (Macalalag et al., 2010; Zarske et al., 2004).

By supplementing the EiE® curriculum with focused conversations about the science content connected to the engineering modules, we speculate that we were able to help teachers remember science content they had forgotten or teach them something new. It is important to interpret the overall finding of increased science content performance carefully. The design of this study does not allow for to us to determine with certainty that the increases in science content knowledge were because teachers learned new information or that the intervention helped to recollect their science memories.

Findings from this study make several important implications regarding engineering education training for elementary teachers. First, authors acknowledge that best practices in professional development for teachers speak to the need for long term, sustained, and situated professional development (Loucks-Horsley, Stiles, Mundry, Love, \& Hewson, 2010). However, when elementary teachers have a true lack of knowledge and understanding of the content area (i.e., engineering) even one training can help to alleviate their uncertainties and misconceptions. The teachers in this study made tremendous strides in their understandings of technology and the work of an engineer. As such, we recommend that teachers and schools seek out targeted engineering education professional development. Second, the teachers in this study also made significant gains in science content knowledge on exams that were intended for use with elementary-aged children. Similar to previous studies (e.g., Czerniak \& Haney, 1998) this finding further indicates that elementary teachers are ill prepared to teach elementary science. This should raise a red flag to teacher educators everywhere that more time needs to be spent helping both preservice and in-service elementary teachers to deepen their conceptual 


\section{Engineering Education in the Elementary School}

understanding of science content. Third, this study suggests that even a short training experience can elevate teachers' self-efficacy for teaching engineering. Teachers tend to avoid teaching a content for which they have low self-efficacy (Riggs, 1995). Teachers need opportunities to engage in engineering practices so that they may experience how engineering practices are tied to areas that they are already teaching. Finally, as workshop providers and researchers, we noticed a qualitative difference within our participants that may be linked to these outcomes. All but one teacher attended this training with at least one colleague from their school. This may suggest that the teachers were allowed to tread these new engineering waters together and build an engineering education community within their building and across schools. Further, more study is needed on understanding how attending professional development with teachers from the same building differs from teachers who attend without a colleague from their school. In summary, as teacher educators we need to learn more about different avenues for elementary engineering education training and working with elementary teachers to enhance their understanding of engineering concepts and practices.

It is important to note that this study only focused on pre to post gains and did not follow teachers over time to determine if content gains were retained or if/how participants implemented the workshop activities into their classrooms. While the current study illustrates that short-term gains in content knowledge and teaching efficacy can be achieved through targeted professional development, further longitudinal studies should be conducted to determine the lasting impacts of these gains on teachers as well as on student learning. 


\section{Engineering Education in the Elementary School}

\section{References}

Appleton, K. (2003). Science pedagogical content knowledge and elementary school teachers. In K. Appleton (Ed.), Elementary science teacher education; International perspectives on contemporary issues and practice (pp. 31-54). Mahwah, NJ: Lawrence Erlbaum Associates.

Banilower, E. R., Smith, P. S., Weiss, I. R., Malzahn, K. A., Campbell, K. M., \& Weis, A. M. (2013). Report of the national survey of science and mathematics education. Chapel Hill. NC: Horizon Research, Inc.

Brophy, S., Klein, S., Portsmore, M., \& Rogers, C. (2008). Advancing engineering education in P-12 classrooms. Journal of Engineering Education, (97)3, 369-387. doi: 10.1002/j.21689830.2008.tb00985.x

Capobianco, B. M., Diefes-dux, H. A., Mena, I., \& Weller, J. (2011). What is an engineer? Implications of elementary school student conceptions for engineering education. Journal of Engineering Education, 100(2), 304-328. doi: 10.1002/j.2168-9830.2011.tb00015.x

Cohen, J. (1988). Statistical power analysis for the behavioral sciences (2nd ed.). Hillsdale, NJ: Lawrence Erlbaum Associates.

Cope, C., \& Ward, P. (2002). Integrating learning technology into classrooms: The importance of teachers' perceptions. Educational Technology \& Society, 5(1), 67-74.

Cunningham, C. (2018). Engineering in elementary STEM education: Curriuclum design, instruction, learning, and assessment. New York, NY: Teachers College Press. 


\section{Engineering Education in the Elementary School}

Cunningham, C. M., \& Carlsen, W. S. (2014). Teaching engineering practices. Journal of Science Teacher Education, 25(2), 197-210. doi: 10.1007/s10972-014-9380-5

Cunningham, C. M., \& Kelly, G. J. (2017). Epistemic practices of engineering for education. Science Education, 101(3), 486-505. https://doi.org/10.1002/sce.21271

Cunningham, C, M., Knight, M. T., Carlsen, W. S., \& Kelly, G. (2007). Integrating engineering in middle and high school classrooms. International Journal of Engineering Education, 23(1), 3-8.

Cunningham, C. M. \& Lachapelle, C. P. (2014). Designing engineering experiences to engage all students. In S. Purzer, J. Strobel, \& M. Cardella (Eds.), Engineering in pre-college settings: Synthesizing research, policy, and practices (pp. 117-142). Lafayette, IN: Purdue University Press.

Cunningham, C. M. \& Lachapelle, C. P. (2016). Designing engineering experiences to engage all students. Educational Designer, 3(9), 1-26. http://www.educationaldesigner.org/ed/ volume3/issue9/article31

Cunningham, C. M., Lachapelle, C. P., \& Keenan, K. (2010). Elementary teachers’ changing ideas about STEM and STEM pedagogy through interaction with a pedagogically supportive STEM curriculum. Presented at the P-12 Engineering and Design Education Research Summit, Seaside, OR.

Cunningham, C. Lachapelle, C., \& Lindgren-Streicher, A. (2005). Assessing elementary school students' conceptions of engineering and technology. Proceedings of the 2005 American Society for Engineering Education Annual Conference \& Exposition, Portland, OR. 


\section{Engineering Education in the Elementary School}

Czerniak, C., \& Haney, J. (1998). The effect of collaborative concept mapping on elementary preservice teachers' anxiety, efficacy, and achievement in physical science. Journal of Science Teacher Education, 9(4), 303-320. doi: 10.1023/A:1009431400397

DeJarnette, N. K. (2012). America's children: Providing early exposure to STEM (science, technology, engineering, and math) initiatives. Education, 133(1), 77-84.

Donna, J. D. (2012). A model for professional development to promote engineering design as an integrative pedagogy within STEM education. Journal of Pre-College Engineering Education Research, 2(2), 1-8. doi: 10.5703/1288284314866

Duncan, D., Diefes-Dux, H., \& Gentry, M. (2011). Professional development through engineering academies: An examination of elementary teachers' recognition and understanding of engineering. Journal of Engineering Education, 100(3), 520-539.

Gibson, S., \& Dembo, M. (1984). Teacher efficacy: A construct validation. Journal of Educational Psychology, 76(4), 569-582. doi: 10.1037/0022-0663.76.4.569

Guskey, T. R., \& Passaro, P. D. (1994). Teacher efficacy: A study of construct dimensions. American Educational Research Journal, 31, 627-643. doi:

$10.3102 / 00028312031003627$

Hall, C., Dickerson, J., Batts, D., Kauffmann, P., \& Bosse, M. (2011). Are we missing opportunities to encourage interest in STEM fields? Journal of Technology Education, $23(1), 32-46$.

Hammack, R. (2016). Elementary teachers' perceptions of engineering, engineering design, and their abilities to teach engineering: A mixed methods study. Retrieved from Proquest Dissertations and Theses (10188936). 


\section{Engineering Education in the Elementary School}

Hammack, R. \& Ivey, T. A. (in press). Elementary teachers' perceptions of engineering and engineering design. Journal of Research in STEM Education.

Hammack. R. \& Ivey, T. A. (2017). Examining elementary teachers' engineering self-efficacy and engineering teacher efficacy. School Science and Mathematics, 117(2) 52-62.

Hester, K., \& Cunningham, C. M. (2007). Engineering is Elementary: An engineering and technology curriculum for children. Proceedings of the 2007 the American Society for Engineering Education Annual Conference \& Exposition, Honolulu, HI.

Katehi, L., Pearson, G., \& Feder, M. (2009). The status and nature of k-12 engineering education in the United States. The Bridge: Linking Engineering and Society. 39(3), 5-10. Retrieved from http://www.nae.edu/TheBridge

Knezek, G., Christensen, R., \& Tyler-Wood, T. (2011). Contrasting perceptions of STEM content and careers. Contemporary Issues in Technology and Teacher Education, 11(1), 92-117.

Lachapelle, C. P., \& Cunningham, C. M. (2017). Elementary engineering student interests and attitudes: A comparison across treatments. Proceedings of the American Society for Engineering Education Annual Conference \& Exposition, Columbus, $\mathrm{OH}$.

Lachapelle, C.P., Hertel, J.D., Jocz, J., \& Cunningham, C. M. (2013, April). Measuring students' naïve conceptions about technology. Presented at the NARST Annual International Conference, Rio Grande, Puerto Rico.

Litowitz, L. S. (2014). A curricular analysis of undergraduate technology and engineering teacher preparation programs in the United States. Journal of Technology Education, $25(2), 73-84$ 


\section{Engineering Education in the Elementary School}

Loucks-Horsley, S., Stiles, K. E., Mundry, S., Love, N., \& Hewson, P. W. (2010). Designing professional development for teachers of science and mathematics. Thousand Oaks, CA: Sage Publications.

Macalalag, A., Lowes, S., Guo, K., Tirthali, D., McKay, M., \& McGrath, E. (2010). Teacher professional development in grades 3-5: Fostering teachers' and students' content knowledge in science and engineering. Proceedings of the 2010 American Society for Engineering Education Annual Conference \& Exposition, Louisville, KY.

Maltese, A.V., \& Tai, R.H. (2010). Eyeballs in the fridge: Sources of early interest in science. International Journal of Science Education, 32(5), 669-685. doi: $10.1080 / 09500690902792385$

Nadelson, L., Sias, C., \& Seifert, A. (2016). Challenges for implementing engineering into the K-12 curriculum: Indicators of K-12 teachers' propensity to adopt innovation. Proceedings of the 2016 American Society for Engineering Education Annual Conference \& Exposition, New Orleans, LA.

National Academy of Engineering and National Research Council. (2009). Engineering in K-12 education: Understanding the status and improving the prospects. Washington, DC: The National Academies Press. https://doi.org/10.17226/12635

National Research Council. (2010). Standards for K-12 engineering education?. Washington, DC: The National Academies Press. https://doi.org/10.17226/12990

National Research Council. (2012). A framework for K-12 science education: Practices, crosscutting concepts, and core ideas. Washington, DC: The National Academies Press. https://doi.org/10.17226/13165 


\section{Engineering Education in the Elementary School}

NGSS Lead States. (2013). Next generation science standards: For states, by states. Washington, DC: The National Academies Press.

Orr, J., Quinn, P., \& Rulfs, J. (2007). Assessment results from a three-year project to teach engineering on grades K-6. Proceedings of the 2007 American Society for Engineering Education Annual Conference \& Exposition, Honolulu, HI.

Oware, E., Capobianco, B., \& Diefes-Dux, H. A. (2007, October). Young children's perceptions of engineers before and after a summer engineering outreach course. Presentation at the $37^{\text {th }}$ Annual ASEE/IEEE Frontiers in Education Conference, Milwaukee, WI.

Reimers, J.E., Farmer, C. L., \& Klein-Gardner, S. S. (2015). An introduction to the standards for preparation and professional development for teachers of engineering. Journal of PreCollege Engineering Education Research, 5(1), 40-60. http://dx.doi.org/10.7771/21579288.1107

Riggs, I. (1995, April). The characteristics of high and low efficacy elementary teachers. Paper presented at the annual meeting of the National Association for Research in Science Teaching, San Francisco.

Rogers, C., \& Portsmore, M. (2004). Bringing engineering to elementary school. Journal of STEM Education: Innovations and Research, 5(3), 17-28.

Sargianis, K., Yang, S., \& Cunningham, C. (2012). Effective engineering professional development for elementary educators. Proceedings of the 2012 American Society for Engineering Education Annual Conference \& Exposition, San Antonio, TX.

Shulman, L. S. (1986). Those who understand: Knowledge growth in teaching. Educational Researcher, 15(2), 4-14. Retrieved from http://www.jstor.org/stable/1175860 


\section{Engineering Education in the Elementary School}

Sun, Y., \& Strobel, J. (2013). Elementary Engineering Education (EEE) adoption and expertise development framework: An inductive and deductive study. Journal of Pre-College Engineering Education Research, 3(1), Article 4. Retrieved from http://docs.lib. purdue.edu/jpeer/vol3/iss1/4/

Tschannen-Moran, M., Woolfolk Hoy, A., \& Hoy, W. K. (1998). Teacher efficacy: Its meaning and measure. Review of Educational Research, 68(2), 202-248.

Utley, J., Moseley, C., \& Bryant, R. (2005). Relationship between science and mathematics teaching efficacy of preservice elementary teachers. School Science and Mathematics, 105(2), 40-45. https://doi.org/10.1111/j.1949-8594.2005.tb18040.x

Wilkins, J. L. M. (2009) Elementary school teachers' attitudes toward different subjects. The Teacher Educator, 45(1), 23-36. doi: 10.1080/08878730903386856

Wyss, V. L., Heulskamp, D., \& Siebert, C. J. (2012). Increasing middle school student interest in STEM careers with videos of scientists. International Journal of Environmental \& Science Education, 7(4), 501-522.

Yasar, S., Baker, D., Robinson-Kurpius, S., Krause, S., \& Roberts, C. (2006). Development of a survey to assess K-12 teachers' perceptions of engineers and familiarity with teaching design, engineering, and technology. Journal of Engineering Education, 95(3), 205-216.

Yoon, S. Y., Evans, M. G., \& Strobel, J. (2014). Validation of the Teaching Engineering SelfEfficacy Scale for K-12 Teachers: A Structural Equation Modeling Approach. Journal of Engineering Education, 103(3), 463-485. https://doi.org/10.1002/jee.20049

Zarske, M., Sullivan, J. F., Carlson, L. E., \& Yowel, J. L. (2004). Teachers teaching teachers: Linking k-12 engineering curricula with teacher professional development. Proceedings 


\section{Engineering Education in the Elementary School}

of the 2004 American Society for Engineering Education Annual Conference \& Exposition, Salt Lake City, UT.

\section{Acknowledgements}

This study was funded by an Oklahoma State Department of Education Mathematics and Science Partnership grant, the OSU College of Education, and the Center for Research on STEM

Teaching and Learning. The ideas in this paper are those of the authors and do not necessarily reflect the views of OSU.

Table 1

Summary statistics for participants' scores on What is Technology? at three time points.

\begin{tabular}{lcccc}
\hline & N & Minimum & Maximum & Median \\
\hline Baseline & 29 & 45 & 100 & 100.00 \\
Post1-workshop1 & 29 & 75 & 100 & 100.00 \\
Post2-workshop2 & 28 & 80 & 100 & 100.00 \\
\hline
\end{tabular}

Table 2

Summary statistics for participants' scores on What is an Engineer? at three time points.

\begin{tabular}{lcccc}
\hline & $\mathrm{N}$ & Minimum & Maximum & Median \\
\hline Baseline & 29 & 63.16 & 100.00 & 68.42 \\
Post1-workshop1 & 28 & 63.16 & 100.00 & 89.47 \\
Post2-workshop2 & 28 & 63.16 & 100.00 & 89.47 \\
\hline
\end{tabular}




\section{Engineering Education in the Elementary School}

Table 3

Summary statistics for participant's scores on content covered in Engineering is Elementary (EiE) (®) workshop.

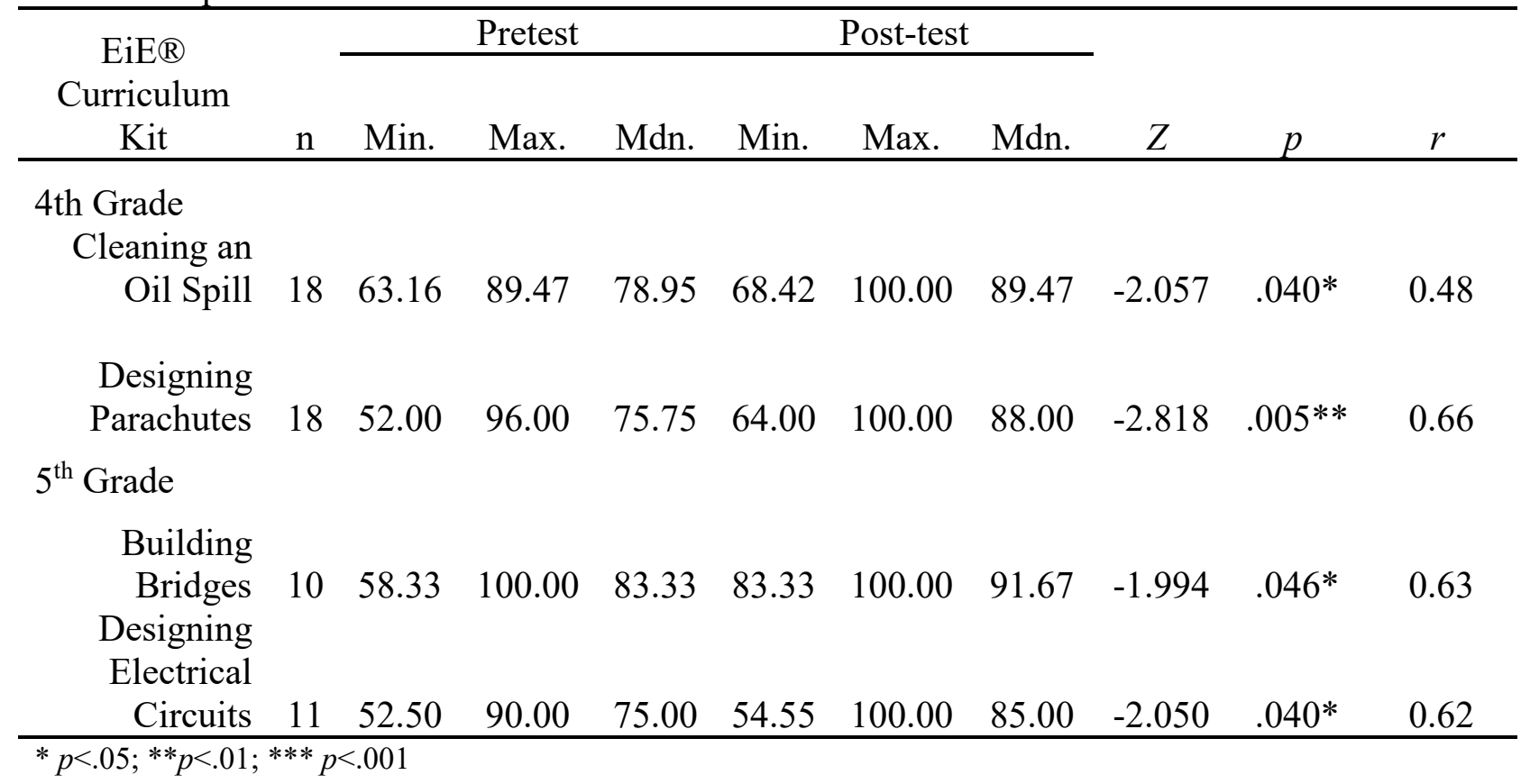




\section{Engineering Education in the Elementary School}

Table 4

Summary statistics for participants' $(n=29)$ scores on Teaching Engineering Self-Efficacy Scale.

\begin{tabular}{lrcccccccc}
\hline \multirow{2}{*}{ Subscale } & \multicolumn{3}{c}{ Pretest } & \multicolumn{7}{c}{ Post-test } & & \\
\cline { 2 - 6 } & Min. & Max. & Mdn. & Min. & Max. & Mdn. & $Z$ & $p$ & $r$ \\
\hline \multirow{2}{*}{ TESS-Overall } & 46 & 129 & 98 & 50 & 138 & 115 & -3.610 & $<.001^{* *}$ & 0.67 \\
KS & 15 & 49 & 35 & 17 & 54 & 45 & -4.001 & $<.001^{* *}$ & 0.74 \\
ES & 8 & 24 & 20 & 8 & 24 & 20 & -2.694 & $.007^{*}$ & 0.50 \\
DS & 10 & 30 & 25 & 10 & 30 & 25 & -1.925 & .054 & 0.36 \\
OE & 10 & 29 & 21 & 15 & 30 & 25 & -2.732 & $.006^{*}$ & 0.51 \\
\hline
\end{tabular}

Note: KS - Engineering Pedagogical Content Knowledge Self-efficacy subscale; ES - Engineering Engagement Self-efficacy subscale; DS - Engineering Disciplinary Self-efficacy subscale; OE - Engineering Outcome Expectancy subscale; $* p<.01 ; * * p<.001$ 